\title{
Removal of Ammonium Ions from Gypsum Slurry in the Process of Desulphurisation of Flue Gases
}

\author{
Miroslav Př́hoda ${ }^{1}$, Mária Čarnogurská ${ }^{2 *}$, Roman Pavlov ${ }^{3}$ \\ ${ }^{1}$ VŠB - Technical University of Ostrava, Faculty of Metallurgy and Materials Engineering, 17. listopadu 15, 0strava - Poruba, 708 00, Czech Republic \\ ${ }^{2}$ Technical University of Košice, Faculty of Mechanical Engineering, Vysokoškolská 4, 04200 Košice \\ ${ }^{3}$ Slovenské elektrárne, a. S., member of the group Enel, Thermal power plant Vojany, 07672 Vojany
}

\begin{abstract}
Miroslav Príhoda, prof. Ing., CSc., he is a graduate of Faculty of Metallurgy at Mining University in Ostrava. Currently works at the Department of Thermal Engineering at Faculty of Metallurgy and Materials Engineering, VŠB - Technical University of Ostrava and is a authority for heat processes within industrial and municipal sphere. His research is concentrated on Mathematical and Physical Modeling of Thermal Processes, Thermal Work of Basic Units of Continuous Casting Equipment, Temperature Conditions in Metal Recuperators, Utilization of Steel Enthalpy at Metallurgical Plants, Determination of Thermal Conductivity and Thermal Diffusivity at High Temperatures. From all of her significant publications there are 16 scientific articles published in Web of Knowledge database, 35 scientific articles published in Scopus database and many other research publications.
\end{abstract}

Mária Čarnogurská, prof. Ing., CSc., is a graduate of Faculty of Mechanical Engineering, Technical University in Kosice (1977). Currently works as a Head of Department of Power Engineering at Faculty of Mechanical Engineering at a. m. university. Her long-term professional focus is the area of power engineering. Her research is concentrating on mathematical and physical modeling of processes and effects applied in power engineering, the flow of various media in energy machines and equipment as well as the exploitation of unused heat energy in diverse industrial applications. She is the author of 4 monographs. From all of her significant publications there are 10 scientific articles published in Web of Knowledge database, 3 scientific articles published in Scopus database and many other research publications.

Roman Pavlov, Ing., he is a graduate of Faculty of Mechanical Engineering, Technical University of Košice. He graduated the power machines and equipments field of study in 2007. Currently he works in Slovenské elektrárne, a. s., Thermal power plant Vojany.

Abstract: The article deals with the proposed methodology for the removal of ammonium ions from the gypsum slurry in the Vojany Slovakia (EVO) power plant. The suspension (slurry) is formed as a by-product of the treatment process of the flue gas desulphurization and denitrification, when ammonia water is being fed to the flue gas. Most of the ammonia, which does not participate in the chemical reaction, escapes together with the flue gas into the absorber of the desulfurization device. By washing such flue gases, large quantities of gypsum slurry are created, which contain ammonium ions. Gypsum slurry is admixed to the "stabilizer" in its production, where it comes into contact with the adhesive agent $(\mathrm{CaO})$, whilst releasing ammonia. Based on the analysis of the current state of denitrification and desulphurization at EVO Vojany, a methodology, more precisely described 
in the article, was proposed for the removal of ammonium ions from the gypsum slurry.

Keywords: Denitrification, desulphurization, gypsum suspension (slurry), ammonium ions.

\section{Introduction}

At the combustion of fossil fuels, not only emerging pollutants [1] to [4] and [6], [7] are closely monitored, but also other indicators that characterize the quality of the combustion process. At the combustion of coal, such indicator is e.g. the quality of ash (its composition) and the quality of flue gases. At ashes, their selected ingredients, such as $\mathrm{SiO}_{2}$ $\mathrm{Al}_{2} \mathrm{O}_{3}, \mathrm{Fe}_{2} \mathrm{O}_{3}, \mathrm{CaO}, \mathrm{MgO}, \mathrm{TiO}_{2}, \mathrm{Na}_{2} \mathrm{O}, \mathrm{K}_{2} \mathrm{O}, \mathrm{SO}_{3}[5]$, [9], are usually monitored. The proportion of the stated components in ash varies (even at the coal from the same coal mine) in relatively wide limits and for the particular coal it is always determined experimentally.

At fuel gases, especially their composition, is monitored. The composition of the fuel gases is influenced, among other factors, by various additives, which are fed to the combustion process in order to e.g. reduce the melting point of slag, to remove nitrogen oxides or other pollutants. In works [10], [11], the results from the combustion of high sulphur coal with $\mathrm{CaO}$ additive, in various ratios, are presented. In case of using a higher amount of $\mathrm{CaO}$ than $30 \%$, a product of cement type with permanently fixed sulphur without any further technological adaptations, can be acquired from the ashes.

To reduce the emissions of nitrogen in the Vojany (EVO) power plant, a selective non-catalytic reduction is used. In this reduction, ammonia is injected directly into the flue gas. Ammonia reacts with $\mathrm{NO}_{x}$, whilst forming nitrogen and water. To start the reaction, the required temperature is between $850^{\circ} \mathrm{C}$ to $1100^{\circ} \mathrm{C}$. At lower temperatures, the reduction process requires a longer reaction time than is possible to achieve in the combustion device. As a result of this, the reduction of nitrogen is low, and the release of a large amount of ammonia into the flue gas occurs. The most of the ammonia not included in the reaction in the process of denitrification, gets into the absorber of the desulphurisation device. The combustion gases from electrostatic precipitators are also directly supplied to the absorber. By the treatment of flue gases after the denitrification process, a large amount of gypsum slurry containing ammonium ions is thus created, and this suspension has to be disposed of. Currently, gypsum slurry is admixed to the "stabilizer", where it comes into contact with the adhesive agent $(\mathrm{CaO})$, whilst releasing ammonia. This process is accompanied by a large release of ammonia. In case that the stabilizer disposes of the ammonium ions, it can be used further. Dosing of the diluted ammonia water (with a 5\% ammonium) at the stated temperature ensures that the reagent $\left(\mathrm{NH}_{3}\right)$ is released for the given reaction, the result of which is water and nitrogen.

In the EVO plant, black semi-anthracite coal with an average calorific value of $25 \mathrm{MJ}^{\mathrm{kg}}{ }^{-1}$ is being combusted and the flue gas is also high in $\mathrm{SO}_{2}$ content. The flue gas is cleaned in the desulphurization device. The $\mathrm{SO}_{2}$ content in the flue gases depends especially from the sulphur content of the fuel, of the ash ability to bind sulphur, the steam (formed from water) content in the flue gas and of the excess air. Among the most widely used methods of non-generative procedure of desulfurization belongs limestone scrubbing. The flue gases are scrubbed in it by an aqueous solution or aqueous emulsion of limestone [8].

The following text deals with the results of the research of the ammonia water dosing into the fuel gas stream, in the process of denitrification and desulphurisation. So far, no information was investigated nor published concerning the amount and quality of the appearing gypsum slurry in such a process, from a semi-anthracite coal type.

\section{Analysis of the flue gas desulphurisation method in the EVO Vojany power plant}

The flue gases are cleaned from the sulphur oxides (SOx), by an aqueous solution or aqueous emulsion of limestone. The scheme of the flue gas washer (scrubber) is on Fig. 1. The advantage of the wet limestone scrubbing is the high desulphurization efficiency of $\mathrm{SO}_{2}$ (90 to 97\%), the retention of part of the ash and the trace compounds of heavy metals and high reliability of the device. The resulting product is commercially usable gypsum (energy gypsum). The disadvantage of this method is the formation of a larger amount of technological wastewater (gypsum slurry) arising from flue gas scrubbing in the absorber, which contains ammonium ions. 


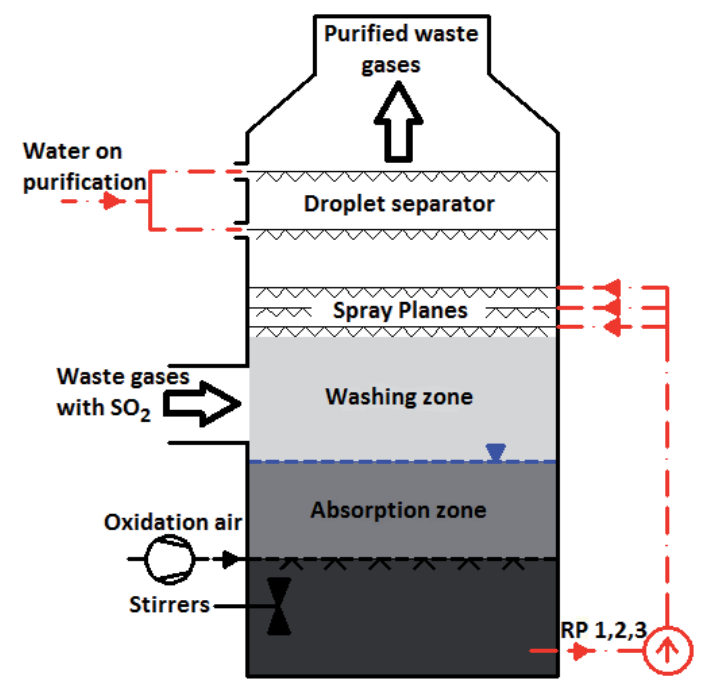

Fig. 1: Scheme of the Flue Gas Treatment in the Absorber.

\subsection{Reactions going on in the absorber}

The absorption of $\mathrm{SO}_{2}$ itself goes on in the upper part of the absorber, where the flue gases come into contact with the scrubbing - limestone suspension, supplied by the RP 1, 2, 3 circulation pumps (Fig. 1). The limestone suspension is formed by the mixture of the grinded powder limestone with the process water, so as it has the concentration of solid particles of 15 to $25 \%$. The suspension is injected to the flue gases, against their flow direction and in three planes arranged one above the other. The scrubbing suspension is continuously mixed by mixing appliances in the bottom part of the absorber.

The reactions in the absorber go on according to the following scheme

a) absorption

$$
\begin{aligned}
& \mathrm{SO}_{2}+\mathrm{H}_{2} \mathrm{O} \leftrightarrow \mathrm{H}_{2} \mathrm{SO}_{3} \\
& \mathrm{SO}_{3}+\mathrm{H}_{2} \mathrm{O} \leftrightarrow \mathrm{H}_{2} \mathrm{SO}_{4}
\end{aligned}
$$

\section{b) reaction with limestone}

In the solution, $\mathrm{SO}_{2}$ reacts with the limestone particles of the scrubbing suspension and forms calcium sulphate (sulphite)

$$
\mathrm{CaCO}_{3}+\mathrm{H}_{2} \mathrm{SO}_{3} \leftrightarrow \mathrm{CaSO}_{3}+\mathrm{CO}_{2}+\mathrm{H}_{2} \mathrm{O}
$$

\section{c) oxidation}

Calcium sulphite reacts via the mid-formation of the bisulphite (equation 4), with the oxygen contained in the flue gas (equation 5), turning into gypsum - calcium sulfate di-hydrate

$$
\begin{aligned}
& \mathrm{CaSO}_{3} \cdot \mathrm{H}_{2} \mathrm{O}+\mathrm{SO}_{2}+\mathrm{H}_{2} \mathrm{O} \rightarrow \\
& \rightarrow \mathrm{Ca}\left(\mathrm{HSO}_{3}\right)_{2}+\mathrm{H}_{2} \mathrm{O} \\
& \mathrm{Ca}\left(\mathrm{HSO}_{3}\right)_{2}+1 / 2 \mathrm{O}_{2}+2 \mathrm{H}_{2} \mathrm{O} \rightarrow \\
& \rightarrow \mathrm{CaSO}_{4} \cdot 2 \mathrm{H}_{2} \mathrm{O}+\mathrm{SO}_{2}+\mathrm{H}_{2} \mathrm{O}
\end{aligned}
$$

Since additional oxygen is needed for this reaction, compressed air produced in the oxidizing air station, is supplied to the absorber. At the same time, reactions of $\mathrm{CaCO}_{3}$ and $\mathrm{NH}_{3}$ with $\mathrm{H}_{2} \mathrm{SO}_{4}, \mathrm{HCl}, \mathrm{HF}$, leading to the formation of calcium and ammonium salts of the relevant acids, are completed.

$$
\begin{aligned}
& \mathrm{CaCO}_{3}+\mathrm{H}_{2} \mathrm{SO}_{4} \leftrightarrow \mathrm{CaSO}_{4}+\mathrm{CO}_{2} \uparrow+\mathrm{H}_{2} \mathrm{O} \\
& \mathrm{CaCO}_{3}+2 \mathrm{HCl} \leftrightarrow \mathrm{CaCl}_{2}+\mathrm{CO}_{2} \uparrow+\mathrm{H}_{2} \mathrm{O} \\
& \mathrm{CaCO}_{3}+2 \mathrm{HF} \leftrightarrow \mathrm{CaF}_{2}+\mathrm{CO}_{2} \uparrow+\mathrm{H}_{2} \mathrm{O} \\
& 2 \mathrm{NH}_{3}+\mathrm{H}_{2} \mathrm{SO}_{4} \leftrightarrow\left(\mathrm{NH}_{4}\right)_{2} \mathrm{SO}_{4} \\
& \mathrm{NH}_{3}+\mathrm{HCl} \leftrightarrow \mathrm{NH}_{4} \mathrm{Cl} \\
& \mathrm{NH}_{3}+\mathrm{HF} \leftrightarrow \mathrm{NH}_{4} \mathrm{~F}
\end{aligned}
$$

Gypsum slurry, with a concentration of solid particles of about 13\%, is drawn from the absorber by pumps for further processing. By means of the technology of removal of ammonium ions, we can get from it the residual part of the unreacted ammonia from denitrification process (i.e. ammonium salts $\left.\left(\mathrm{NH}_{4}\right)_{2} \mathrm{SO}_{4}, \mathrm{NH}_{4} \mathrm{Cl}, \mathrm{NH}_{4} \mathrm{~F}\right)$. The ammonia obtained in the form of $23 \%$ ammonia water, is transported to the storage tank of ammonia water and reused in the process of denitrification. Gypsum slurry is used in the production of the stabilizer.

Pure flue gases are, after their release from the absorber, cooled to about $50^{\circ} \mathrm{C}$ and saturated with steam, they are removed by the wet stack of the absorber to the ambient atmosphere.

\subsection{Methodology of the removal of ammonium ions}

The ammonium removal technology from gypsum slurry is related to the reaction of the inlet gypsum suspension with calcium hydroxide $\mathrm{Ca}(\mathrm{OH})_{2}$. The expulsion of ammonia from the suspension occurs through the effect 
of the supplied steam, whilst by the subsequent condensation, we get 23\% ammonia water and waste water (output gypsum slurry).

The concentration of ammonia ions in the inlet gypsum slurry is max. $16 \mathrm{~g} \mathrm{NH}_{4}^{+} \cdot 1^{-1}$. To remove them, a 20\% suspension of calcium hydroxide (milk of lime), which is prepared by the reaction of burnt lime $(\mathrm{CaO})$ with process water $\left(\mathrm{H}_{2} \mathrm{O}\right)$, is used. When mixing the milk of lime with the gypsum suspension a chemical reaction takes place, the result of which is the formation of $\mathrm{NH}_{3}$

Based on laboratory tests, it has been discovered,

$\mathrm{NH}_{3}+\mathrm{HF} \leftrightarrow \mathrm{NH}_{4} \mathrm{~F}$

that at a 50\% of milk of lime overflow, the reaction time necessary for $\mathrm{NH}_{3}$ formation is max. 1 hour. Consequently, it is necessary to strip of (to separate) ammonia from the suspension by steam and divide the resulting ammonia water after condensation by rectification, to $23 \%$ ammonia water, as a recyclable material to the denitrification lutter water (the output gypsum suspension) containing about $20 \mathrm{~g}$ of ammonia in form of $\mathrm{NH}_{4}^{+} \cdot 1^{-1}$ (max. $100 \mathrm{~g} \mathrm{NH}_{4}^{+} \cdot 1^{-1}$ ), which is then incorporated in the production of the stabilizer without the release of ammonia.

\section{Experimental research of the removal of ammonium ions}

Colorimetric method with the participation of Nessler reagent has been used for the experimental research of ammonia ions. The following chemicals and devices were used: Sodium hydroxide: $(10 \% \mathrm{NaOH}$ solution), sulphuric acid (solution $0.05 \mathrm{~mol}^{\prime} \cdot \mathrm{I}^{-1}$ ), Nessler's reagent (reagent specific for the determination of $\mathrm{NH}_{4}^{+}$), ammonium sulfate $\left(\mathrm{NH}_{4}\right)_{2} \mathrm{SO}_{4}$, the device for steam (water vapour) distillation (the Parnas - Wagner, colorimeter - optical instrument to determine the colour changes depending on the concentration).

The procedure of experimental determination of the ammonia ions in the gypsum slurry was the following. To the distillation flask (Fig. 2) $10 \mathrm{ml}$ of filtrated gypsum suspension is poured. $20 \mathrm{ml}$ of $0.05 \mathrm{~mol}^{-1} \mathrm{I}^{-1}$ solution of sulphuric acid is poured into the model receiver and diluted with water so as the mouth of the connector was immersed below the surface of the solution. About $10 \mathrm{ml}$ of sodium hydroxide is added into the distillation flask and is distilled as long as to produce $100 \mathrm{ml}$ of distillate. When the distillation is completed, the mouth of the connector is rinsed, the entire content of the model receiver will be placed into a volumetric flask with a volume of $200 \mathrm{ml}$ and filled up with distilled water up to the $200 \mathrm{ml}$ sign. 50 $\mathrm{ml}$ is pipetted from the distillate and placed into a $100 \mathrm{ml}$ volumetric flask. $2 \mathrm{ml}$ of Nessler's reagent is added to the distillate and filled up with distilled water up to the sign at $100 \mathrm{ml}$ level. The solution is mixed well and after 30 minutes of being left, the intensity of the yellow colour is measured by the colorimeter at a wavelength of $420 \mathrm{~nm}$. A concrete value corresponds to the given intensity of colouring $\mathrm{NH}_{4}^{+}$[5].

The values of the ammonia ions in the input and output gypsum suspension (slurry), obtained by the procedure described above, are stated in Table 1. The composition of the gypsum suspension is stated in Table 2. View of a real operating equipment, that is built on the basis of the results from the laboratory research for ammonium ions removing, is shown in Fig. 3.

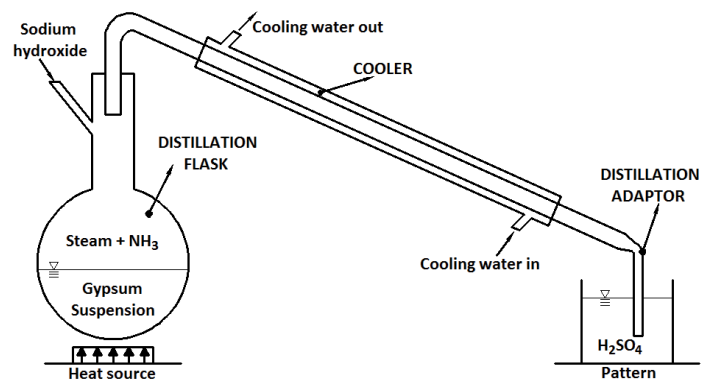

Fig. 2: The laboratory device measuring the concentration of ammonia.

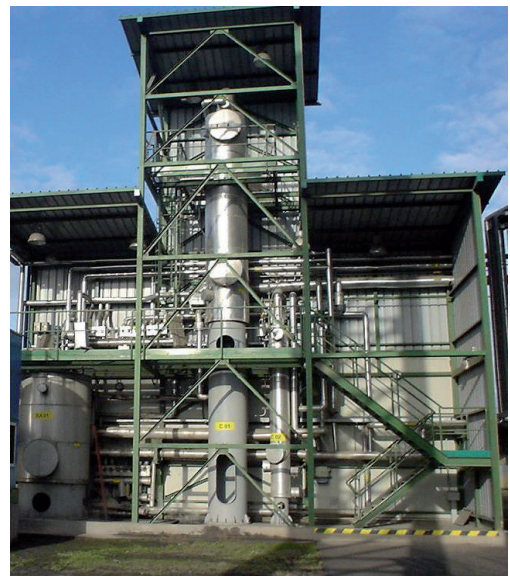

Fig. 3: Operating equipment for removing ammonium ions. 
Table 1: The Results of the Analyses of the Content of Ammonium lons in Gypsum Suspension and the Efficiency of their Removal.

\begin{tabular}{|l|l|l|l|}
\hline Sample number & \multicolumn{1}{c}{$\begin{array}{c}\text { Input gypsum suspension } \\
\left(\mathbf{m g} \cdot \mathbf{l}^{\mathbf{1}}\right)\end{array}$} & $\begin{array}{c}\text { Outlet gypsum suspension } \\
\left(\mathbf{m g} \cdot \mathbf{l}^{\mathbf{1}}\right)\end{array}$ & $\begin{array}{c}\text { Effectiveness of the ammonia ions } \\
\text { removal (\%) }\end{array}$ \\
\hline 1 & 7633 & 46 & 99.40 \\
\hline 2 & 7426 & 45 & 99.39 \\
\hline 3 & 7091 & 44 & 99.39 \\
\hline 4 & 6870 & 42 & 99.39 \\
\hline 5 & 7103 & 42 & 99.41 \\
\hline 6 & 6966 & 43 & 99.38 \\
\hline 7 & 6870 & 42 & 99.39 \\
\hline 8 & 6721 & 41 & 99.39 \\
\hline 9 & 6835 & 41 & 99.40 \\
\hline 10 & 6740 & 41 & 99.39 \\
\hline 11 & 6608 & 39 & 99.41 \\
\hline 12 & 6736 & 40 & 99.40 \\
\hline Mean value & $\mathbf{6 9 6 6 . 6}$ & $\mathbf{4 2 . 2}$ & $\mathbf{9 9 . 3 9}$ \\
\hline
\end{tabular}

Table 2: Composition of the Gypsum Suspension.

\begin{tabular}{|l|l|}
\hline ammonia & $\mathrm{NH}_{3}$ \\
\hline water & $\mathrm{H}_{2} \mathrm{O}$ \\
\hline calcium hydroxide & $\mathrm{Ca}(\mathrm{OH})_{2}$ \\
\hline calcium oxide & $\mathrm{CaO}$ \\
\hline magnesium hydroxide & $\mathrm{Mg}(\mathrm{OH})_{2}$ \\
\hline calcium sulfate dihydrate & $\mathrm{CaSO} \cdot 2 \mathrm{H}_{2} \mathrm{O}$ \\
\hline magnesium sulfate & $\mathrm{MgSO} 4$ \\
\hline ammonium sulfate & $\left(\mathrm{NH}_{4}\right)_{2} \cdot \mathrm{SO}_{4}$ \\
\hline
\end{tabular}

\section{Discussion}

Desulphurization technology is based on the principle of the wet limestone scrubbing/washing of flue gases by means of a limestone suspension. As a result of a chemical reaction, calcium sulphite is formed in the absorber, which is subsequently oxidized with oxygen from the supplied air to calcium sulfate - gypsum. The final product resulting from the desulphurisation process is thus a gypsum suspension thickened in a hydro-cyclone, or dewatered energy gypsum with humidity values up to $10 \%$. Following the removal of ammonia ions, the gypsum suspension is only suitable for mixing into stabilizer, without subsequent dewatering. After dewatering however, dewatered energy gypsum can be utilized also for commercial purposes - raw material suitable for the production of gypsum plaster, wall plaster, plasterboards or porous concrete. Energy gypsum can be used in the cement industry, mainly as a solidification regulator. This function of the gypsum depends from the content of $\mathrm{CaSO}_{4} \cdot 2 \mathrm{H}_{2} \mathrm{O}$ and the content of solid pollutants according to the STN EN197-1 standard.

\section{Conclusions}

Since 1. 1. 2007, all major sources of pollution are obliged, according to the Act No. 393/1998 Coll., achieve the emission limits set out by the Government Regulation No. 92/1996 Coll. From this date, it is not possible to operate old coal fired blocks (e.g. EVO I) with classical firing, without flue gas desulphurisation.

The process of desulphurisation presented in this paper allows to ensure, for the mentioned devices, the required emission limits, which are more stringent and became valid after 1. 1. 2010, when for sulphur oxide the max. allowable amount was set at the level of $1700 \mathrm{mg} \cdot \mathrm{m}^{-3}$. At the older operating sites, it is possible to achieve this value by the methodology described in this paper.

\section{Acknowledgments}

This paper was elaborated in frame of tasks related to the solution of the project VEGA 1/0004/14 and SP2015/86-FMMI VŠB TUO. 


\section{References and notes}

[1] Ahn, J., Kim, H. J., Choi, K. S. 2010. Oxy-fuel combustion boiler for CO2 capturing: $50 \mathrm{~kW}$ class model test and numerical simulation, J. Mech. Sci. Technol., 24 (10): p. 2135-2141, DOI: 10.1007/s12206-010-0711-y.

[2] Čarnogurská, M., Př́hoda, M., Pyszko, R., Širillová, L., Palkóci, J. 2014. The influence of calcite on the ash flow temperature for semi-anthracite coal from Donbas district. Chem. Process Eng. 35 (4): p. 515-525, DOI: 10.2478/cpe-2014-0038.

[3] Čarnogurská, M., Př́hoda, M., Koško, M., Pyszko, R. 2012. Verification of pollutant creation model at dendromasa combustion. J. Mech. Sci. Technol., 26 (9): p. 4161-4169, DOl: 10.1007/s12206-011-0913-y.

[4] Čarnogurská, M., Příhoda, M., Brestovič, T. 2011. Modelling of nitrogen oxides formation applying dimensional analysis. Chem. Process Eng., 32 (3): p. 175-184, DOI: 0.2478/v10176011-0013-7.

[5] Javorský, P., Fojtíková, D., Kašal, V. 1987. Chemické rozbory $\checkmark$ zemědělských laboratořích. Ministerstvo zemědělství a výživy ČSR, Praha.

[6] Kočanová, S., Lukáč, L. 2014. The impact of the composition of the wood gas to emissions after combustion of wood gas. The Holistic Approach to Environment, 4 (3): p. 111-117.

[7] Moroń, W., Czajka, K., Ferens, W., Babul, K., Szydełko, A., Rybak, W. 2013. NOx and SO2 emission during OXY-coal combustion. Chem. Process Eng., 34 (3), p. 337-346. DOI: 10.2478/ cpe-2013-0027.

[8] Pavlov, R. 2007. Odstraňovanie amónnych iónov zo sadrovcovej suspenzie $\vee$ EVO Vojany $\vee$ procese odsírenia. Diplomová práca. SjF TU v Košiciach.

[9] Sambor, A., Szymanek. A. 2012. Investigation of the distribution of chemical components in selected landfill layers and fly ash fractions. Chem. Process Eng., 33 (2): p. 221-229, DOI: 10.2478/v10176-012-0019-9.

[10] Wang, W., Luo, Z., Shi Z., Cen, K. 2011. Experiments and Modelling of Ash Mineral Evolution in Burning High-Sulphur Coal with Lime. Energy Fuels, 25(1): p. 130-135. DOI: 10.1021/ ef1014346.

[11] Szlek, A., Jandačka, J., Nosek, R. 2010. Numerical modelling of coal combustion in domestic boiler. Archivum combustionis, 30 (3): p. 167-175.

[12] Zavila, O., Bojko, M., Kozubková, M., Danihelka, P., Baudišová, B., Maléřová, L. Čarnogurská, M. 2014. CFD Analysis of the Influence of Meteorological Conditions on Motion of Ammonia. Acta Mechanica Slovaca, (18) 1: p. 64-70. 